\title{
Predation by a SHORTFin MAKo SHARK, Isurus oxyRINCHUS, RAFinesQue, 1810, ON A PANTROPICAL SPOTTED DOLPHIN, STENELLA ATENUATTA, CALF in Central Atlantic waters
}

\author{
Milena Santos Monteiro ${ }^{1, *}$, Teodoro Vaske Júnior ${ }^{2}$, \\ Taciana Martins Barbosa ${ }^{3}$ and Maria Danise de Oliveira Alves ${ }^{1,4}$
}

Keywords: predation, short fin mako shark, spotted dolphin, Isurus oxyrinchus, Stenella attenuata

This report details a shark attack on a calf of pantropical spotted dolphin Stenella attenuata (Gray 1846), and discusses some evidences of the possible causes of the attack. The female calf was found in the stomach of a shortfin mako shark, Isurus oxyrinchus, Rafinesque, 1810, in central Atlantic waters. The entire dolphin was the only prey item inside the stomach. The shark, $210 \mathrm{~cm}$ in total length, was caught by the tuna longliner "Chun Kuo 289" in February 2006, in the position $01^{\circ} \mathrm{N}, 26^{\circ} \mathrm{W}$, approximately $500 \mathrm{~km}$ eastward of the Saint Peter and Saint Paul Archipelago, at $5000 \mathrm{~m}$ local depth. The stomach of the shark was extracted onboard, stored frozen, and later analyzed in the laboratory. The dolphin retrieved from it was $85.0 \mathrm{~cm}$ in total length, weighed $5.5 \mathrm{~kg}$, had unerupted dentition, presented vibrissae on the upper rostrum, and had no spots, all considered features of a newborn (Perrin, 2001). It was sectioned by one clear bite, which divided the body of the dolphin in three segments. The segment of the bite went from the posterior end of the dorsal fin to the caudal peduncle. This segment measured $24.0 \mathrm{~cm}$ in widh, which is equivalent to the width of the shark's mouth. The dolphin's body was in good condition, including the natural colors (Figure 1). Several small scars made by the teeth of the shark were observed along the dolphin's body, and the skin had started to peel off. External measurements of the dolphin, taken following Norris (1961), are shown in Table 1.

Thirty-eight teeth were counted on each side of both mandibles using an $\mathrm{x}$-ray photograph of the lateral-posterior position.
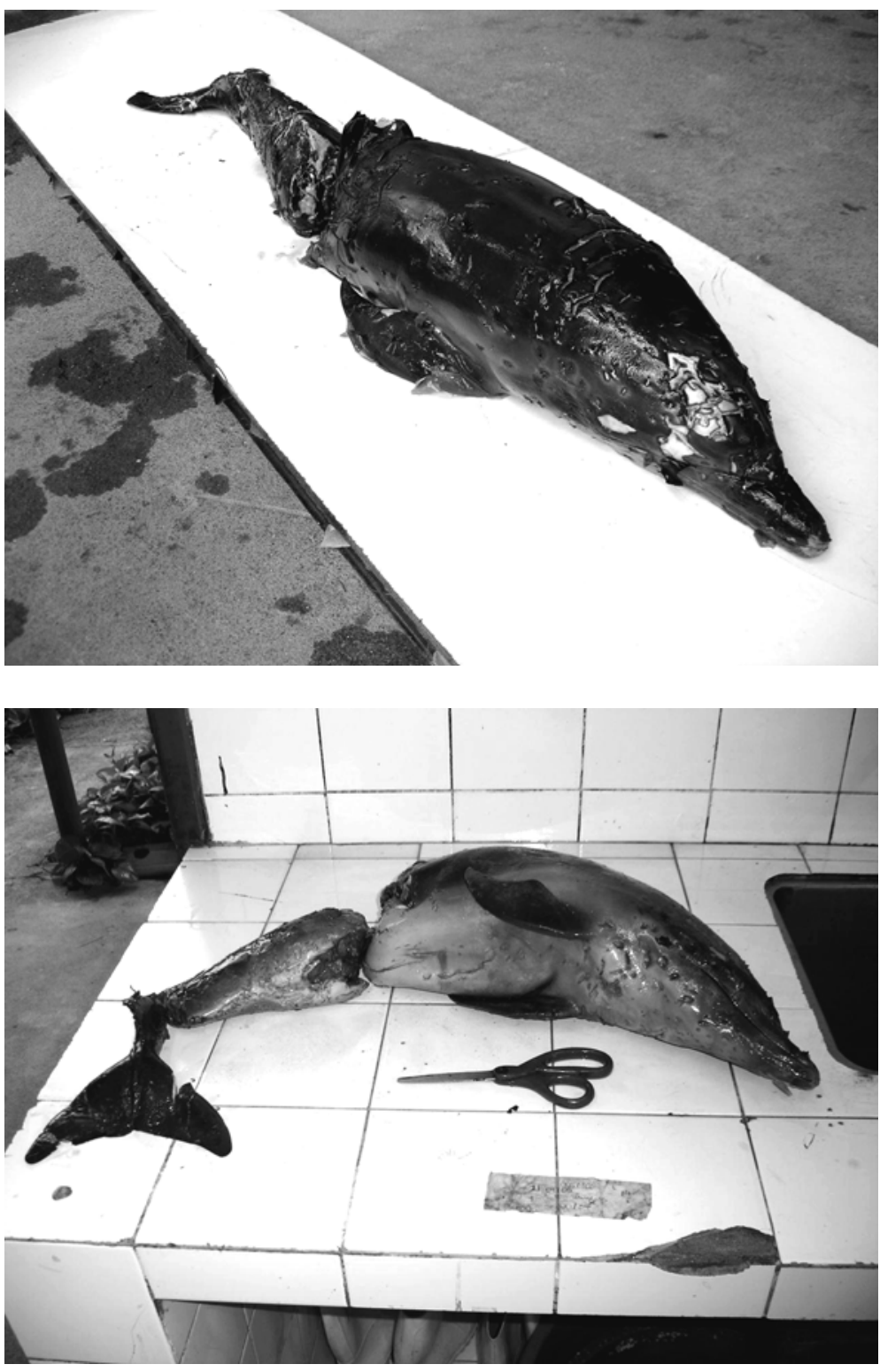

Figure 1. A pantropical spotted dolphin preyed upon by a shorfin mako shark caught by a tuna longliner in central Atlantic waters.

\footnotetext{
${ }^{1}$ Departamento de Zoologia, Centro de Ciências Biológicas, UFPE, Avenida Arquitetura, s/n. Cidade Universitária, 50730-540, Recife, PE, Brazil.

* Corresponding author, e-mail: golfomila@yahoo.com.br.

${ }^{2}$ Departamento de Pesca e Aqüicultura, UFRPE. Av. Dom Manuel de Medeiros, s/n, Dois Irmãos, 52171-900, Recife, PE, Brazil. E-mail: vaske@ig.com.br.

${ }^{3}$ E-mail: tacianamartins@hotmail.com.

${ }^{4}$ E-mail: danisealves@hotmail.com.
} 
Table 1. Measurements of the Stenella atenuatta calf, according Norris (1961), retrieved from the stomach of a shorfin mako shark caught by a tuna longliner in central Atlantic waters.

\begin{tabular}{lc}
\hline \hline MEASUREMENTS & LENGTH (cm) \\
\hline \hline Total length & 85.0 \\
Eye-maxilla (tip of upper jaw to center eye) & 15.5 \\
\hline Melon-maxilla (tip of upper jaw to apex melon) & 3.8 \\
Mouth length (gape) & 18.2 \\
Ear-maxilla (tip of upper jaw to external auditory meatus) & 17.0 \\
Spiracle-maxilla (tip of upper jaw to to blowhole alone midline) & 14.5 \\
\hline Dorsal fin - maxilla (tip of upper jaw to tip of dorsal fin) & 39.0 \\
Pectoral fin - maxilla (tip of upper jaw to tip of pectoral fin) & 19.8 \\
Anus - maxilla (tip of upper jaw to center anus) & 53.0 \\
Flipper width & 17.5 \\
\hline Pectoral fin outside (anterior insetion to tip flipper) & 14.4 \\
\hline Pectoral fin inside (flipper axilla to tip) & 10.5 \\
\hline Pectoral fin width (flipper width maximum) & 4.9 \\
Dorsal fin base & 10.0 \\
\hline Flukes width & 7.8 \\
\hline \hline
\end{tabular}

Evidence of predator-prey and competitive interactions between sharks and dolphins can be observed through scarring patterns and wounds on live dolphins (Corkeron et al., 1987; Heithaus, 2001; Celona et al., 2006), on carcasses beached or floating at sea, on direct observations of attacks by sharks on live dolphins (Maldini, 2003; Gibson, 2006), and in shark stomach content studies (Crovetto et al., 1992; Di Beneditto, 2004). Shark attacks on cetaceans are known worldwide, but are mostly commonly reported in coastal populations with only few records in cetaceans with open ocean distributions (Wood et al., 1970). This predatory pressure has a strong influence on dolphin behavior, habitat use, and group size (Wells et al., 1980, 1987; Heithaus, 2001; Heithaus and Dill, 2002, 2006; Crespi-Abril et al., 2003; Gibson, 2006).

The shortfin mako is a common, extremely active and fast shark. It is found in oceanic waters where they are commonly caught by longline fishery in tropical and subtropical oceans (Compagno, 2001; Campana et al., 2005). Dietary studies shows that this shark is a top predator, feeding on large teleosts (e.g. tunas, swordfish, billfish), as well as other sharks, rays, cephalopods, sea turtles and unidentified small cetacean material (including a pelagic dolphin), salps, isopods, penaeid shrimp, sponges, sargassum weed, and occasional stones and other detritus (Last and Stevens, 1994; Compagno, 2001). Experiments of depth preferences concluded that mako sharks spend around $90 \%$ of their time in surface waters between 0 and 12m (Sepulvida et al., 2004), which reinforce the probability of encounters with cetaceans near the surface.
Due to the good condition of the dolphin, and the absence of fetal folds, it is suggested that the dolphin was alive when the shark attacked. The bite near the tail sectioned the vertebral column, and the tail remained connected only by the skin and muscles. This fact probably caused the immobilization of the dolphin thus facilitating the shark to swallow the entire body in one dash. The arched shape of the bite in the flank indicates that the shark probably attacked from the below, the dolphin being probably near the surface. In a fatal attack performed by a tiger shark (Galeocerdo cuvier) on a juvenile pantropical spotted dolphin in Hawaii, it was observed that the shark bit the caudal peduncle to immobilize the dolphin (Maldini, 2003). In Hawaii, spotted dolphins spent substantial proportions of their time in shallow waters (less than 10m) in part to avoid the tiger shark that prefer deeper waters (Baird et al., 2001). Sharks may also attack Clymene dolphins (Stenella clymene), as evidenced by a probable shark bite on a dolphin stranded in Texas (Jefferson et al., 1995). An aggressive interaction was observed between sharks and possible Clymene dolphins in the Gulf of Mexico, involving apparent cooperative behavior by the dolphins, including defense of the young (Springer, 1967). Gibson (2006) also reported non-fatal attacks on bottlenose dolphin (Tursiops truncatus) calves in Australia by carcharhinid sharks that also bit the caudal peduncle of the calves that were 10 to $20 \mathrm{~m}$ far from their mothers. Corkeron (1987) found a relatively high proportion of nursing females in Moreton Bay in Australia with fresh visible shark bites and suggested that theses adults, or their calves, are more vulnerable to shark predation. 
Relationships between dolphins and sharks may vary according to the size and number of sharks, size and group composition of dolphins, and the moment that the shark is detected (Mann and Watson-Capps, 2005). As pointed out by Wood et al. (1970), offshore dolphins are likely to be less preyed upon by sharks. Offshore species such as $S$. attenuata form large aggregations in the Atlantic Ocean and are more likely to be able to detect and avoid predators (Heithaus, 2001). Conversely, a predation attempt in such an open environment may be more likely to lead to death (Heithaus, 2001), as shown here. In this study, the calf probably ventured far from its mother for some time, which enabled the shark to attack, taking advantage of the lack of maternal supervision and the good visual conditions typically found in open waters.

\section{Acknowledgements}

The authors are grateful to the researchers who collected the shark stomach onboard, and to Drs. Eduardo Resende Secchi, Paulo César Simões-Lopes, Lidio Nascimento and Ignácio Benites Moreno for the help with the dolphin identification. Thanks to Sandro Rogério Soares and Fabrício Bezerra de Sá who provided technical informations and x-ray photographs for helping the dolphin species identification. Paulo César Simões-Lopes and Ignácio Benites Moreno reviewed the manuscript.

\section{References}

BAird, R.W., Ligon, A.D., HoOker, S.K. ANd Gorgone, A.M. (2001) Subsurface and nighttime behaviour of pantropical spotted dolphins in Hawaii. Canadian Journal of Zoology 79: 988-996

Campana, S.E., Marks, L. AND JoyCE, W. (2005) The biology and fishery of shortfin mako sharks (Isurus oxyrinchus) in Atlantic Canadian waters. Fisheries Research 73: 341-352.

Celona, A., De Maddalena, A. and Comparetto, G. (2006) Evidence of predatory attack on bottlenose dolphin Tursiops truncatus by a great white shark Carcharodon carcharias in the Mediterranean Sea. Annals for Istran and Mediterranean Studies, Series Historia Naturalis 16(2): 159-164.

Compagno, L.J.V. (2001) Sharks of the world. An annotated and illustrated catalogue of shark species known to date. Volume 2: Bullhead, mackerel and carpet sharks (Heterodontiformes, Lamniformes and Orectolobiformes). FAO Species Catalogue for Fisheries Purposes No. 1, vol. 2. Food and Agriculture Organization of the United Nations, Rome, Italy, $269 \mathrm{pp}$.

Corkeron, P.J., Morris, R.J. and Bryden., M.M. (1987) Interactions between bottlenose dolphins and sharks in Moreton Bay, Queensland. Aquatic Mammals 13(3): 109-113.

Crespi-Abril, A.C., Garcia, N.A., Crespo, E.A. and Coscarella, M.A. (2003) Consumption of marine mammals by broadnose sevengill shark Notorynchus cepedianus in the Northern and Central Patagonian shelf. The Latin American Journal of Aquatic Mammals 2(2): 101-107.
Crovetto, A., Lamilla J. and Pequeno, G. (1992) Lissodelphis peronii, Lacépède 1804 (Delphinidae, Cetacea) within the stomach contents of a sleeping shark, Somniosus cf. pacificus, Bigelow and Schroeder 1944, in Chilean waters. Marine Mammal Science 8(3): 312-314.

Di Beneditto, A.P. (2004) Presence of franciscana dolphin (Pontoporia blainvillei) remains in the stomach of a tiger shark (Galeocerdo cuvieri) captured in southeastern Brazil. Aquatic Mammals 30: 311-314.

GiBSon, Q.A. (2006) Non-lethal shark attack on a bottlenose dolphin (Tursiops sp.) calf. Marine Mammal Science 22(1): 190-197.

Gray, J.E. (1846) On the cetaceous animals. Pp. 13-53 in The zoology of the voyage of H.M.S.Erebus and Terror under the command of Captain Sir James Clark Ross during the years 1839 to 1843 . Volume 1. Mammalia, birds. RiCHARDSON, J. AND Gray, J.E. (Eds). E.W.Jansen, London, United Kingdom.

Heithaus, M.R. (2001) Predator-prey and competitive interactions between sharks (Order Selachii) and dolphins (Suborder Odontoceti): a review. Journal of Zoology 253: 53-68.

Heithaus, M.R. And DilL, L.M. (2002) Food availability and tiger shark predation risk influence bottlenose dolphin habitat use. Ecology 83: 480-491.

Heithaus, M.R. And Dill, L.M. (2006) Does tiger shark predation risk influence faring habitats use by bottlonose dolphins at multiple spatial scales? Oikos 114: 257-264.

Jefferson, T.A., Odell, D.K. and Prunier, K.T. (1995) Notes on the biology of the Clymene dolphin (Stenella clymene) in the northern Gulf of Mexico. Marine Mammal Science 11: $564-573$.

LAST, P.R., AND SteVENS, J.D. (1994) Sharks and rays of Australia. CSIRO Iinformation Services. East Melbourne, Australia. 513p.

MaldinI, D. (2003) Evidence of predation by a tiger shark (Galeocerdo cuvier) on a spotted dolphin (Stenella atenuatta) off Oahu, Hawaii. Aquatic Mammals, 29(1): 84-87.

MANN, J. AND WATSON-CAPPS, J. (2005) Surviving at sea: Ecological and behavioral predictors of calf mortality in Indian Ocean bottlenose dolphins (Tursiops sp.). Animal Behaviour 69: 899-909.

NoRRIS, K.S. (1961) Standardized methods for measuring and recording data on the smaller cetaceans. Journal of Mammalogy 42(4): 471-476.

Perrin, W.F. (2001) Stenella attenuata. Mammalian Species 683: 1-8.

Perrin, W.F., Coe, J.M. and Zweifel, J.R. (1976) Growth and reproduction of the spotted porpoise, Stenella attenuata, in the offshore eastern tropical Pacific. Fishery Bulletin 74: 229-269.

Sepulvida, C.A., Kohin, S., Chan, C., Vetter, R. and Graham, J.B. (2004) Movement paterns, depth preferences, and stomach temperatures of free-swimming juvenile mako sharks, Isurus oxyrinchus, in the Southern California Bight. Marine Biology 145: 191-199.

SpRINGER, S. (1967) Porpoises vs. sharks. Page 27 in Conference of the shark-porpoise relationship (Anonymous, ed.). American Institute of Biological Sciences, Washington, D.C., USA.

Wells, R.S., Irvine, A.B. And Scott, M.D. (1980) The social ecology of inshore odontocetes. Pages 263-317 in HERMAN, L.M. (Ed). Cetacean behavior: mechanisms and functions. Wiley \& Sons, New York, NY, USA. 
Wells, R.S., Scott, M.D. And Irvine, A.B. (1987) The social structure of free-ranging bottlenose dolphins. Pages 247-305 in Genoways, H.H. (Ed). Current Mammalogy. Volume 1. Plenum Press, New York, NY, USA.
Wood, F.G. JR., Caldwel, D.K. and Caldwell, M.C. (1970) Behavioral interactions between porpoises and sharks. Investigations on Cetacea 2: 264-277.

Received 5 September 2006. Accepted 18 November 2006. 